\title{
The Effect of Learning Environment, Inquiry and Student Learning Interest on Student Social Studies Learning Assessment
}

\author{
Okta Rosfiani ${ }^{1}$, Ma'ruf Akbar $^{2}$, Amos Neolaka $^{3}$ \\ \{rosfianiagus@gmail.com¹, Makrufakbar@unj.ac.id²,octha_mae@yahoo.com³
}

Universitas Negeri Jakarta, Indonesia ${ }^{123}$

\begin{abstract}
This study aims to examine the effect between the learning environment, inquiry, and learning interest in student social studies learning assessment. The participants involved were 130 students from public primary schools in South Jakarta. Data collection consists of social studies learning score, learning environment scale, inquiry scale, and learning interest scale. The results of the study show that the learning environment, inquiry, and learning interest directly influence student social studies learning assessment. Where inquiry and learning interest have a significant effect on student social studies learning assessment.
\end{abstract}

Keywords: Learning environment, inquiry, student learning interest, social studies, assessment.

\section{Introduction}

George, Madan [1] mention, the social sciences are about people-our wealth, our problems and our values. Whereas social studies are ultimately a set of courses that enable students to understand human experiences[2]. The curriculum views social studies in three traditions, ie, social studies as citizenship transmission, social studies as social science and social studies as reflective inquiry[3].

Achievement tests are designed to measure what the student has learned[4]. Such assessment can be applied to both processes and products of performance: processes are ongoing procedures leading to a final result, whereas products are the culminating results accomplished through a series or sequence of procedures[5]. In this model of assessment the allocation of scores, or even the confirmation of correct answers[6].

A positive learning environment significantly correlated with student academic progress, therefore, recommendations were made for the improvement of the learning environment[7]. However, contrary to the above studies, Ebanks findings show the contrary thing that is associations with learner-centered pedagogy were ineffective in the effort to raise student achievement[8].

An inquiry is a dynamic approach to learning and teaching that involves a process of experiencing the natural world. As they pose questions about the information, learners conduct research for genuine reasons, make new discoveries and test their discoveries to generate new knowledge and understanding[9]. Inquiry indicates a positive effect on student learning[10]. 
Learning interest have a positive and significant interactive effect on learning outcomes[11].Infusing student responses to classroom discussions increases student awareness of important issues, increases their knowledge, and enhances student interest in the course [12], [13]. Research Questions, this study aims to examine the effects of the learning environment, inquiry, and learning interest towards student social studies learning assessment

\section{Methods}

Desired sample size, according to Creswell [14]about 30 participants for correlational studies that connect variables. The participants involved were 130 students from public elementary schools in South Jakarta. Participants were selected based on probabilistic sampling using simple random sampling. The method used to determine the precision of parameter estimates in research is path analysis. Data were analyzed using SPSS version 20.0.

Data collection consists of social studies learning score, learning environment scale, inquiry scale, and learning interest scale. All participants received a questionnaire and test package, which consisted of a learning environment questionnaire, inquiry, learning interest, and social studies test.

We measure the cognitive domain of students. We use a range of scores 1-3 to determine the assessment of their social studies. Students work on essays for as many as 8 questions. From the 16 items test criteria were given to participants, 8 test items declared valid and reliable. Valid if the correlation value (Pearson correlation $>\mathrm{r}$ table). Whereas if Cronbach's Alpha $>$ r table $=$ reliable, Cronbach's Alpha $0.700>0.329$.

We measure the affective domain of students towards their learning environment. Researchers develop a measure of attitude through writing own questions. The learning environment referred to in this study is a series of features that affect students' social studies learning that can be structured physically and mentally. There are 15 physically structured items of the learning environment and 15 mentally structured learning environment items. From the 30 items of questionnaires were given to participants, 18 questionnaire items were declared valid and reloable. We use a range of scale 1-3 to measure students feelings toward learning environment. Cronbach's Alpha $0.761>0.329$.

The affective domain of students towards their inquiry is measured. Researchers develop own questions from a series of indicators in inquiry. From 30 items of questionnaires were given to participants, 24 of which were valid and reliable. We use a range of scale 1-3 to measure students feelings toward inquiry. Cronbach's Alpha 0,862 >0.329.

The affective domain of students towards their learning interest is measured. Researchers develop own questions from a series of indicators in learning interest. From 16 items of questionnaires were given to participants, 15 of which were valid and reliable. We use a range of scale 1-3 to measure students feelings toward learning interest. Cronbach's Alpha 0,824 > 0.329. Data were analyzed using SPSS version 20.0. Data analysis in this study was carried out in three stages.

a. Descriptive statistics. To test whether the scores reported by participants are valid and reliable. The score is declared valid if Pearson correlation $>\mathrm{r}$ table. The score is declared reliable if Cronbach's Alpha $>\mathrm{r}$ table. In the social studies learning assessment variable, there are 8 valid and reliable test questions. Learning environment variables have 18 valid and reliable questionnaire items. The Inquiry variable has 24 valid and reliable questionnaire 
items. And in the interest in learning interest, there are 15 valid and reliable questionnaire items.

b. Normality test. To investigate skewness \& kurtosis z-values; Shapiro-Wilk test p-value; and histograms, normal Q-Q plots \& box plots. A Shapiro-Wilk's test (p> .05) [15], [16]and a visual inspection of their histograms, normal Q-Q plots and box plots showed that the exam scores were approximately normally distributed, with a skewness of $0.074(\mathrm{SE}=0.251)$ and a kurtosis 0.128 $(\mathrm{SE}=0.498)[17]-[19]$.

c. Path analysis. To test whether there are a direct influence and indirect influence given by independent variables (learning environment, inquiry, and learning interest) through intervening variables (social studies) on the dependent variable (learning assessment). If the significance value is $<0.05$, there is a direct and significant effect of the independent variable on the dependent variable. The research data set can be accessed in osf.io Open Science Framework.

\section{Results}

Path analysis is carried out between the learning environment toward social studies learning assessment; inquiry toward social studies learning assessment; learning interest towards social studies learning assessment; learning environment toward inquiry; learning environment toward learning interests; and inquiry toward learning interest.

The results of the study demonstrate that the learning environment has a direct effect on social studies learning assessment. The significance value of the learning environment $=0.000$ $<0.05$. R Square value $=0.242$. This shows that the contribution of the influence of the learning environment to the social studies learning assessment is equal to $24.2 \%$, while the remaining $75.8 \%$ is contributed by other variables not included in the study. Meanwhile, for the value Std. Error 1 can be searched by formula SE1 $=\sqrt{ }(1-0.242)=0.870$.

The inquiry has a direct effect on social studies learning assessment. Inquiry significance value $=0,000<0.05$. R Square value $=0.521$. This shows that the contribution of the influence of inquiry on social studies learning assessment is $52.1 \%$, while the remaining $47.9 \%$ is contributed by other variables not included in the study. Meanwhile, for Std. Error 2 values can be searched by formula SE2 $=\sqrt{ }(1-0.521)=0.692$.

Learning interest has a direct effect on social studies learning assessment. The significance value of learning interest $=0,000<0.05$. $\mathrm{R}$ Square value $=0.910$. This shows that the contribution of learning interest in social studies learning assessment is $91.0 \%$, while the remaining $9 \%$ is a contribution from other variables not included in the study. Meanwhile, for the value of Std. Error 3 can be found with the formula SE3 $=\sqrt{ }(1-0.910)=0.3$.

Learning environment has a direct effect on inquiry. The significance value of the learning environment $=0,000<0.05$. $\mathrm{R}$ Square value of 0.284 . This shows that the contribution of the influence of the learning environment to the inquiry is $28.4 \%$, while the remaining $71.6 \%$ is a contribution from other variables not included in the study. Meanwhile, for the value of Std. Error 4 can be found with the formula SE4 $=\sqrt{ }(1-0.284)=0.533$.

Learning environment has a direct effect on learning interest. The significance value of the learning environment $=0,000<0.05$. R Square Value $=0.212$. This shows that the contribution of the influence of the learning environment to learning interest is $21.2 \%$, while the remaining $78.8 \%$ is a contribution from other variables not included in the study. 
Meanwhile, for the value of Std. Error 5 can be searched with the formula SE5 $=\sqrt{ }(1-0.212)$ $=0.888$.

The inquiry has a direct effect on learning interest. Inquiry significance value $=0,000<$ 0.05 . R Square value $=0.555$. This shows that the contribution of the influence of inquiry to interest in learning is equal to $55.5 \%$, while the remaining $44.5 \%$ is a contribution from other variables not included in the study. Meanwhile, for the value of Std. Error 6 can be searched with the formula SE6 $=\sqrt{ }(1-0.555)=0.667$. The following table shows the relationship between learning environment variables, inquiry, and interest in learning towards student social studies learning assessment.

Table 1. The relationship between learning environment variables, inquiry, and interest in learning towards student social studies learning assessment

\begin{tabular}{lllll}
\hline Variable & Sig. & p.05 & $\begin{array}{l}\text { R } \\
\text { Square }\end{array}$ & SE \\
\hline $\begin{array}{l}\text { Learning environment } \rightarrow \text { Social studies } \\
\text { learning assessment }\end{array}$ & .000 & p.05 & .242 & 0.870 \\
Inquiry $\rightarrow$ Social studies learning assessment & .000 & p.05 & .521 & 0.692 \\
Learning interest $\rightarrow$ Social studies learning & .000 & p.05 & .910 & 0.3 \\
assessment & & & & \\
Learning environment $\rightarrow$ Inquiry & .000 & p.05 & .284 & 0.533 \\
Learning environment $\rightarrow$ Learning interest & .000 & p.05 & .212 & 0.888 \\
Inquiry $\rightarrow$ Learning interest & .000 & p.05 & .555 & 0.667 \\
\hline
\end{tabular}

\section{Discussion}

The results showed that the influence of the learning environment on student social studies learning assessment was only $24.2 \%$, very small compared to other variables. This is possible because there are other variable contributions that were not included in the study, but contributed as expressed in the Oonk study which stated that the regional learning environment does not significantly improve learning[20].

The effect of the inquiry on student social studies learning assessment is $52.1 \%$, which is quite large compared to the learning environment. The results of this study are supported by Ellis[21]which mention that students are taught with inquiry learning environments typically enhance student learning, higher scores are achieved than those taught through traditional methods. Learning interest has a direct effect on student social studies learning assessment, which is $91.0 \%$. Learning interest improved significantly higher scores[22].

The results of the study demonstrate that the learning environment affects inquiry by $28.4 \%$. Learning environment had a positive effect on students' ability to managing their research project the depth of learning and their development as autonomous learners, as well as their perception of the research project experience[23].

The study showed the effect of learning environment on learning interest by $21.2 \%$. The

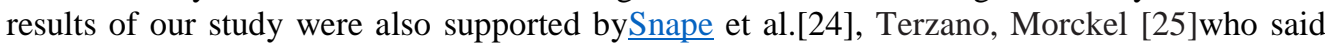
that a significant impact of learning environment on learning interest. Learning environment finally impact on individual interest[26]. The effect of inquiry on learning interest is $55.5 \%$. Inquiry increase involvement[27]. 


\section{Conclusion}

The results of the study show that the learning environment, inquiry, and learning interest directly influence student social studies learning assessment. Where inquiry and learning interest have a significant effect on student social studies learning assessment. Therefore, the results of this study suggest that teachers and parents need to create a learning environment that involves the experience of inquiry, and that encourages students' learning interest. The results of this study also show that stakeholders should make policies that support the inquiry learning environment to increase student learning interest, which not only affects student outcomes in the cognitive domain but also in the affective and psychomotor domains.

\section{Limitation}

There are several limitations to this study. The first limitation is, the number of research samples used is not too large. The second limitation is that the social studies learning test instruments used have not been fully reliable. Further research will investigate the influence of the learning environment, inquiry, and interest in learning on the assessment of learning subjects in science, citizenship, and mathematics which involve more participants and more reliable test instruments.

\section{Acknowledgments}

We would like to thank the Ministry of Technology Research and the Higher Education Republic of Indonesia for their assistance funding.

\section{References}

[1]T. Ado, 'Academic achievement in mathematics: A case study of some selected secondary schools in Yobe State - Nigeria', J. Educ. Pract., vol. 6, no. 34, pp. 40-44, 2015.

[2]E. P. . Badgett, J.L., Designing elementary instruction and assessment. California: Corwin A SAGE Company, 2009.

[3]P. Batra, Social science learning in schools: Perspective and challenges. India: Sage Publications India Pvt Ltd, 2010.

[4]L.-R. . Cheng, 'Creating an optimal language learning environme', Commun. Disord. Q., vol. 30, no. 2 , pp. 69-76, 2009.

[5]D. Cramer, Fundamental statistics for social research. London: Routledge, 1998.

[6]D. Cramer, D., Howitt, The SAGE dictionary of statistics. London: SAGE, 2004.

[7]J. W. Creswell, Educational research: planning, conducting, and evaluating quantitative and qualitative research. Boston: Pearson Education, Inc, 2012.

[8]L. . Doane, D.P., Seward, 'Measuring Skewness', J. Stat. Educ., vol. 19, no. 2, pp. 1-18, 2011.

[9]X. Du, J., Xu, J., Fan, 'Factors affecting online groupwork interest: a multilevel analysis', J. Educ. Comput. Res., vol. 49, no. 4, pp. 481-499, 2013.

[10]R. . Ebanks, 'The influence of learner-centered pedagogy on the achievement of students in title I elementary schools', Northcentral University, 2010. 
[11]M. Eisenman, L., Chamberlin, M., McGahee-Kovac, 'A teacher inquiry group on student-led IEPs: Starting small to make a difference', Teach. Educ. Spec. Educ., vol. 28, no. 3/4, pp. 195-206, 2005.

[12]R. . Ellis, 'Qualitatively different university student experiences of inquiry: Associations among approaches to inquiry, technologies and perceptions of the learning environment', Act. Learn. High. Educ., vol. 17, no. 1, pp. 13-23, 2016.

[13]A. George, A.M., Madan, Teaching social science in schools: NCERT's new textbook initiative. India: SAGE Publications, 2009.

[14]W. . Hall, K., Burke, Making formative assessment work: Effective practice in the primary classroom. London: Open University Press, 2004.

[15]J. Lee, Visualizing elementary social studies methods. USA: John Wiley \& Sons, 2008.

[16]C.-Y. Lee, Y-J., Chao, C-H., Chen, 'The influences of interest in learning and learning hours on learning outcomes of vocational college students in Taiwan: Using a teacher's instructional attitude as the moderator', Glob. J. Eng. Educ., vol. 13, no. 3, pp. 140-153, 2011.

[17]S. . McCann, L.I., Immel , K.R., Kadah-Ammeter, T.L., Adelson, 'The importance and interest of introductory psychology textbook topics: Student opinions at technical college, 2-, and 4-year institutions', Teach. Psychol., pp. 2-6, 2016.

[18]M. Oonk, C., Gulikers, J., Mulder, 'Educating boundary crossing planners: Evidence for student learning in the multistakeholder regional learning environment', J. Plan. Educ. Res., pp. 1-14, 2017.

[19]T. Overton, Assessing learners with special needs: An applied approach. Boston: Pearson, 2012.

[20]Y. . Razali, N.M., Wah, 'Power comparisons of Shapiro-Wilk, Kolmogorov-Smirnov, Liliefors and Anderson-Darling tests', J. Stat. Model. Anal., vol. 2, no. 1, pp. 21-33, 2011.

[21]C. . Rooks, D.L., Maker, 'Inquiry: A teaching approach for gifted visually impaired learners', Gift. Educ. International, vol. 25, pp. 172-187, 2009.

[22]M. . Shapiro, S.S, Wilk, 'An analysis of variance test for normality (complete samples)', Biometrika, vol. 52, no. 3/4, pp. 591-611, 1965.

[23]P. Snape, D.J., Davies, D., Collier, C., Howe, A., Digby, R., Hay, 'The impact of creative learning environments on learners: A systematic literature review', Improv. Sch., vol. 16, no. 1, pp. 21-31, 2013.

[24]B. Stappenbelt, 'Undergraduate mechanical engineering research project work in an action learning environment', Int. J. Mech. Eng. Educ., vol. 37, no. 4, pp. 326-340, 2015.

[25]V. Terzano, K., Morckel, 'SimCity in the community planning classroom: Effects on student knowledge, interests, and perceptions of the discipline of planning', J. Plan. Educ. Res., pp. 1-11, 2016.

[26]K. Tröbst, S., Kleickmann, T., Lange-Schubert, K., Rothkopf, A., Möller, 'Instruction and students' declining interest in science: An analysis of German fourth- and sixth-grade classrooms', Am. Educ. Res. J., vol. 53, no. 1, pp. 162-193, 2016.

[27]N. . Wozniak, 'Enhancing inquiry, evidence-based reflection, and integrative learning with the lifelong eportfolio process: The implementation of integrative eportfolios at stony brook university', J. Educ. Technol. Syst., vol. 41, no. 3, pp. 209-230, 2012.

[28]J. Xu, 'Models of secondary school students interest in homework: A multilevel analysis', Am. Educ. Res. J., vol. 45, no. 4, pp. 1180-1205, 2008. 